\title{
BMJ Global Health The Brazilian health system at crossroads: progress, crisis and resilience
}

\author{
Adriano Massuda, ${ }^{1}$ Thomas Hone, ${ }^{2}$ Fernando Antonio Gomes Leles, ${ }^{3}$ \\ Marcia C de Castro, ${ }^{1}$ Rifat Atun ${ }^{1}$
}

To cite: Massuda A, Hone T, Leles FAG, et al. The Brazilian health system at crossroads: progress, crisis and resilience. BMJ Glob Health 2018;3:e000829. doi:10.1136/ bmjgh-2018-000829

\section{Handling editor Valery Ridde}

Received 13 March 2018

Revised 4 June 2018

Accepted 5 June 2018
Check for updates

(C) Author(s) (or their employer(s)) 2018. Re-use permitted under CC BY-NC. No commercial re-use. See rights and permissions. Published by BMJ.

${ }^{1}$ Harvard TH Chan School of Public Health, Harvard University, Boston, Massachusetts, USA ${ }^{2}$ Public Health Policy Evaluation Unit, School of Public Health, Imperial College London, London, UK

${ }^{3}$ Pan-American Health Organization (PAHO)/World Health Organization in Brazil, Brasilia, Brazil

Correspondence to

Dr Rifat Atun;

ratun@hsph.harvard.edu

\section{ABSTRACT}

The Unified Health System (Sistema Único de Saúde (SUS)) has enabled substantial progress towards Universal Health Coverage (UHC) in Brazil. However, structural weakness, economic and political crises and austerity policies that have capped public expenditure growth are threatening its sustainability and outcomes. This paper analyses the Brazilian health system progress since 2000 and the current and potential effects of the coalescing economic and political crises and the subsequent austerity policies. We use literature review, policy analysis and secondary data from governmental sources in 2000-2017 to examine changes in political and economic context, health financing, health resources and healthcare service coverage in SUS. We find that, despite a favourable context, which enabled expansion of UHC from 2003 to 2014, structural problems persist in SUS, including gaps in organisation and governance, low public funding and suboptimal resource allocation. Consequently, large regional disparities exist in access to healthcare services and health outcomes, with poorer regions and lower socioeconomic population groups disadvantaged the most. These structural problems and disparities will likely worsen with the austerity measures introduced by the current government, and risk reversing the achievements of SUS in improving population health outcomes. The speed at which adverse effects of the current and political crises are manifested in the Brazilian health system underscores the importance of enhancing health system resilience to counteract external shocks (such as economic and political crises) and internal shocks (such as sector-specific austerity policies and rapid ageing leading to rise in disease burden) to protect hard-achieved progress towards UHC.

\section{INTRODUCTION}

After 30 years of progress towards Universal Health Coverage (UHC), ${ }^{1}$ Brazil's Unified Health System (Sistema Único de Saúde (SUS) ) is under major threat from a combination of economic recession, political crisis, ill-conceived austerity policies ${ }^{2}$ and political decisions aimed at reversing the right to health. $^{3}$

Conceived in the late $1980 \mathrm{~s}$ by the civil society as part of the 'Sanitary Reform Movement' (Movimento da Reforma Sanitária) against the military dictatorship, SUS has

\section{Summary box}

Brazil has made good progress towards achieving Universal Health Coverage (UHC) with improvements in population health, but shortages in public funding suboptimal resource allocation and weaknesses in healthcare delivery persist.

- From 2000 to 2014, total health expenditure rose from $7.0 \%$ to $8.3 \%$ of gross domestic product and population coverage with the Family Health Strategy rose from $7.6 \%$ to $58.2 \%$.

- Since 2015, public health expenditure per capita has declined in real terms, while 2.9 million people lost private health plan coverage, violent deaths have increased and there have been outbreaks of infectious diseases

- Economic and political crises, combined with austerity policies, pose a major risk to UHC and health gains achieved Brazil, and elsewhere, with detrimental impact on the poorest and the most vulnerable populations, and require development of resilient health systems.

been widely acknowledged as an example of successful health system reform in Latin America, ${ }^{4}$ and has played a major role in the redemocratisation of Brazil and in the re-establishment of citizens' rights. ${ }^{5}$ Reforms in health system governance and major expansion of primary healthcare (PHC) have contributed to major improvements in health service coverage and access, ${ }^{6}$ and health outcomes. $^{78}$

However, Brazilian health reforms were incomplete, and did not fully address structural weaknesses in the health systemnamely, challenges at the state government level, inadequate financing and inequitable resource allocation. ${ }^{9}$ Consequently, disparities in access to effective care, financial protection and health outcomes persist. ${ }^{10}$ These disparities will likely worsen due to the current economic and political crises and the new long-term austerity measures, ${ }^{11}$ which are testing health system's resilience, ${ }^{12}$ jeopardising the sustainability of $\operatorname{SUS}^{13}$ and 
reversing the hard-achieved improvements in equity, UHC and health outcomes.

We analyse the context that enabled of the expansion of SUS from 2000, the economic and political crises that began in 2014, the austerity policies which followed and the impact of these external and internal shocks on SUS.

External shocks, such as economic and political crises, can trigger cascades of events that adversely affect health systems by increasing unemployment and poverty, reducing funds for health services and increasing demand for social protection programmes (figure 1; blue arrows). ${ }^{2}$ This cascade of events can affect health outcomes and health inequalities through changes in health needs, behaviours and healthcare service use. Political crises, which can be triggered by economic crises, influence social protection and policies for UHC (figure 1; red lines), and could lead to worsening health outcomes through poverty, and reduced coverage of healthcare services. In times of economic crisis, politicians could choose to maintain socially protective policies and protect health and social well-being of populations. However, although evidence from high-income countries shows protective effect of social welfare expenditures and adverse effects of austerity measures, ${ }^{1415}$ few studies have explored the short and long-term effects of economic recessions in middle-income countries, and the protective effect afforded by UHC and social policies. ${ }^{16-18}$

We undertook a literature review and analysed policies and secondary data from governmental sources to examine changes in health financing, health service coverage and resources for health and the effect of the economic and political crises on SUS and population health in Brazil.

\section{EXPANSION OF THE UNIFIED HEALTH SYSTEM IN BRAZIL}

Following the end of the military dictatorship, the 1988 Constitution established 'health as a fundamental right and a responsibility of the State', with provisions to create a unified national health system. At its inception,
SUS, underpinned by the principles of equity, solidary and social participation, aimed to develop a universal, comprehensive and decentralised health system, free of charge at the point of service provision. ${ }^{5}$ However, initial expansion of SUS was limited by weak technical capacity of the federal government and lower levels of administration, inadequate financing stemming from economic instability and postmilitary right-wing governments opposed to social sector investments. ${ }^{9}$ Limited investment in SUS and the transfer of the responsibility for health service provision to municipal governments with variable financial and administrative capacity have led to large disparities in health service coverage and access to healthcare. ${ }^{7}$ However, despite these limitations, Brazil achieved major health system changes, with the development of inclusive decision-making at all levels of government. $^{5}$

In 2002, the right-wing government ceded power with the election of President Luís Inácio 'Lula' da Silva and his left-wing Workers' Party (Partido dos Trabalhadores), which committed to improving health, reducing social disparities and alleviating poverty. During Lula's presidency, economic stability and growth (figure 2) enabled the government to introduce redistributive social assistance policies, which were associated with rising incomes and reductions in unemployment and inequalities. ${ }^{19}$ The favourable political and economic climate allowed greater public funding for SUS. For each level of government, minimum expenditure levels on health were established in 2000 and set in law in 2012. ${ }^{9}$

Between 2002 and 2013, with expansion of SUS, there was near universal access to essential health services, such as immunisations and antenatal care, with improved population health outcomes, and declines in regional health inequalities. ${ }^{6}$ However, despite progress, health inequalities remained a feature of Brazil, mirroring the wealth and income inequalities in the country.

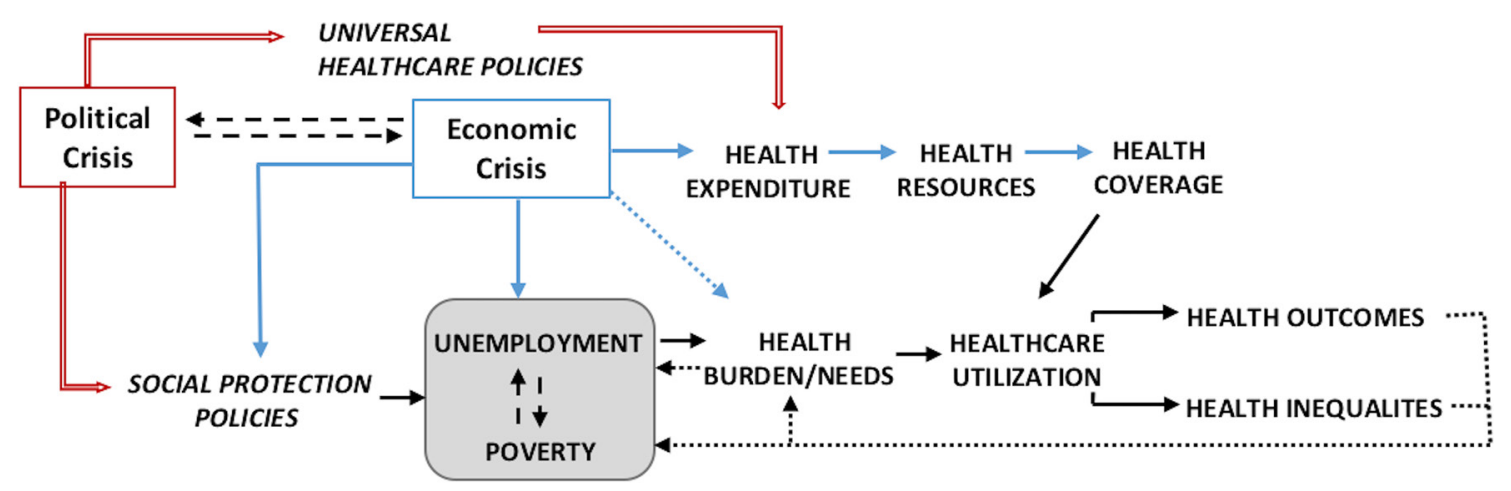

Source : Authors' own work

Figure 1 The political and economic crisis cascade effects. 


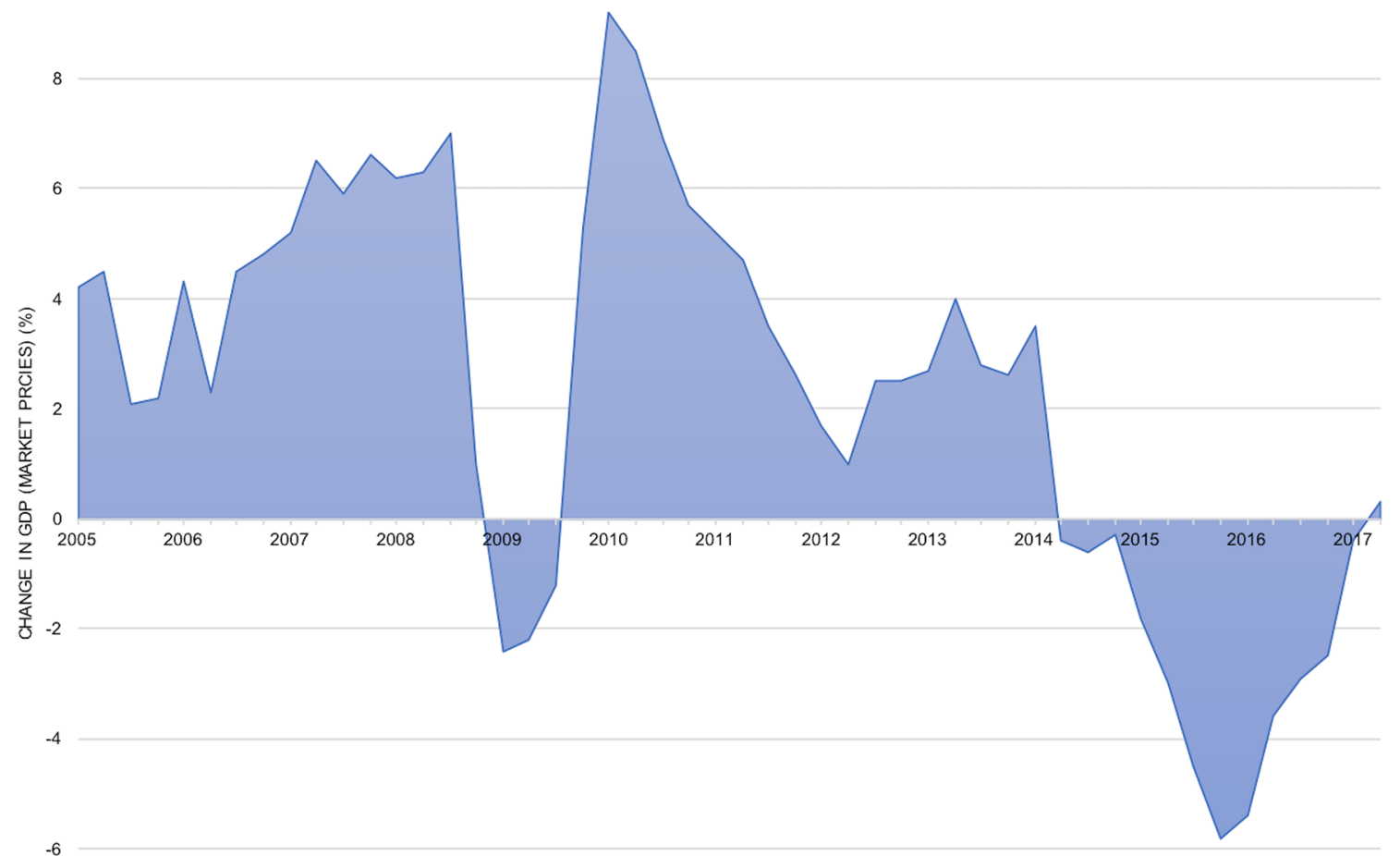

\section{ECONOMIC CRISIS}

The global financial crisis of 2008 only modestly affected Brazil (as its exposure to the global financial system and subprime mortgage markets was limited), but as the global commodity prices weakened and foreign investment fell, economic growth slowed after $2010 .{ }^{19-21}$

In 2014, Brazil experienced its worst recession on record with a sharp fall in the gross domestic product (GDP) growth (figure 2). The recession exposed fundamental weaknesses in the economy, including a burdensome tax system, large informal sector, limited competition, inefficiencies in the public sector, high costs of doing business and high import tariffs. ${ }^{19}$ Economic stimulus policies, including price controls, ad hoc tax breaks, reduced interest rates and subsidised public sector lending, did little to improve the economy. ${ }^{19}$ The recession led to rising unemployment; just in 2015, 1.6 million formal sector jobs were lost.

Weakened consumer and business confidence translated into reduced tax revenues and increasing budgetary pressures, prompting reductions in subsidised lending and removal of price subsidies. ${ }^{19}$ However, the recession, coupled with a rise in international interest rates, led to surging inflation, a rising budget deficit (from $2.7 \%$ of GDP in 2009 to $10.3 \%$ in 2015) ${ }^{19}$ and increasing government debt (from $30.0 \%$ of GDP in January 2014 to $46.6 \%$ of GDP in January 2017). Austerity policies introduced by the government in 2015 led to major cuts in public investments, and in the health and education budgets. ${ }^{11} 13$

\section{POLITICAL CRISIS}

Amid economic turmoil, political instability emerged in 2013, initially involving citizen protests against corruption, and demands for better public services. A series of corruption scandals followed. President Dilma Rousseff was impeached in 2016 due to controversial accusations of financial irregularity. A new centre-right government was subsequently installed, with Michel Temer as the President, who instituted a neoliberal economic reform agenda with privatisation of major state assets. ${ }^{22} \mathrm{~A}$ Constitutional Amendment 95 (EC 95/PEC 55/PEC 241) passed by the Congress in December 2016 limited federal primary expenditure on health over the next 20 years, capping spending in 2017 to $15 \%$ of the Net Current Revenue and from then onwards to 2017 spending levels adjusted for inflation, with a projected decline in health budget of $\mathrm{R} \$ 415$ billion by 2036 . Financing reforms introduced by Ministry of Health ended targeted funding for specific components of SUS (eg, PHC, surveillance, medicines). ${ }^{23}$ National health policies, including Family Health Strategy (FHS) and mental health, were revised, with new regulations for private health insurance aimed at reducing demand for public services and introducing low-cost 'popular health plans' with restricted benefits. $^{2425}$

\section{CHANGES IN HEALTH SYSTEM FINANCING}

In 2000-2014, total health expenditure rose from 7.0\% to $8.3 \%$ of GDP, and per-capita health expenditure 


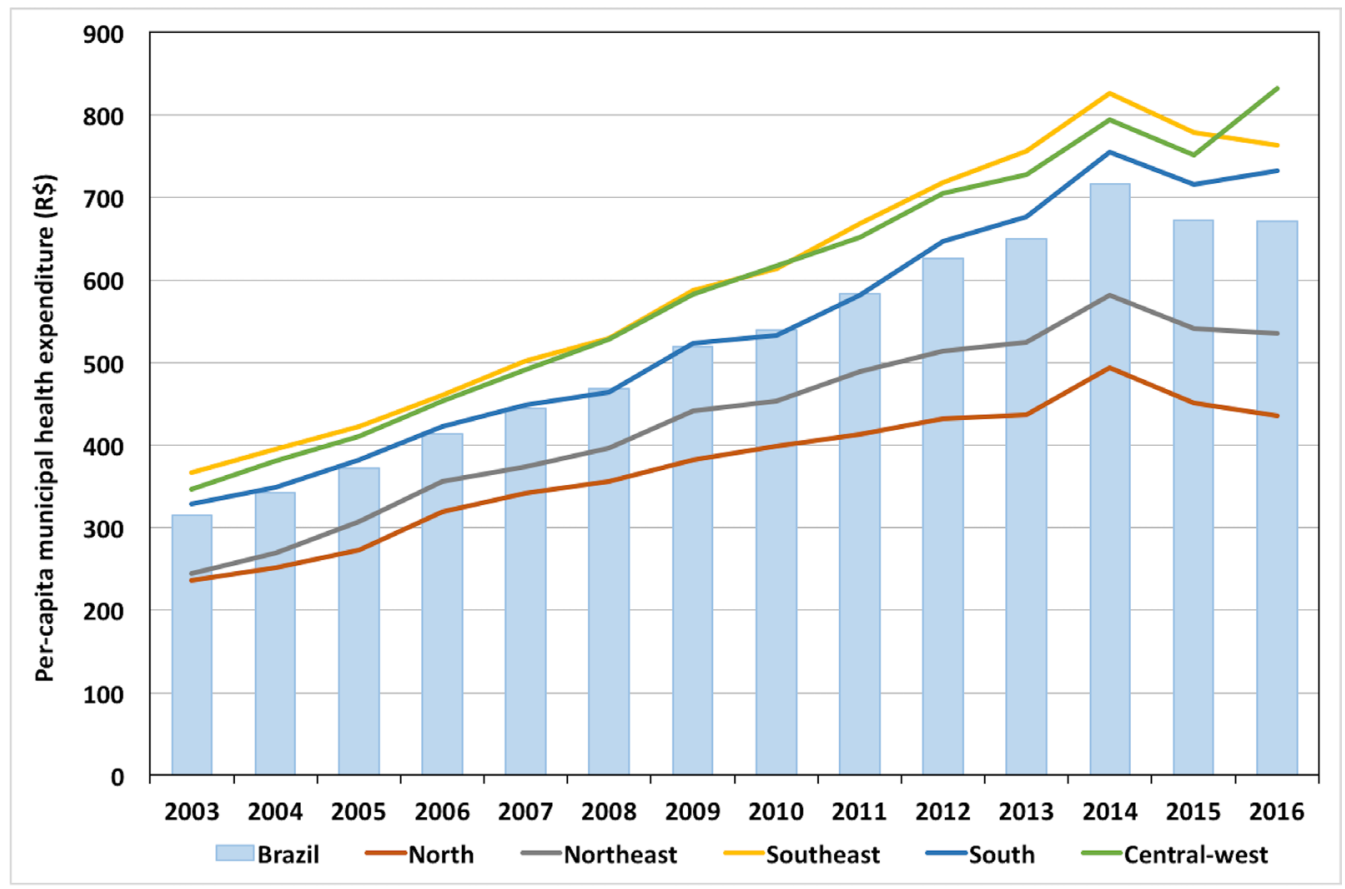

Source: SIOPS/DATASUS (Inflation-adjusted by IGPM / FGV index - October 2017)

Figure 3 Per-capita municipal health expenditure, 2003-2016.

increased from US\$263 in 2000 to US\$947 in 2014. Although the level of total health expenditure is comparable to other countries in Latin America, public expenditure is low for a universal healthcare system and burdens individuals with large out-of-pocket costs. ${ }^{4}$ Brazil has one of the lowest proportion of public spending on health $(46.0 \%)$ in Latin America and the Caribbean (average $51.28 \%)$, in upper middle-income countries $(55.2 \%)$ and in Organization for Economic Cooperation and Development countries $(62.2 \%)$. In addition, although Brazil has reduced out-of-pocket expenditures (as a proportion of private expenditures, part of which is accounted by contributions to private insurance), they still represent a considerable financial burden for households (representing nearly $50 \%$ of private expenditures on health).

The share of expenditure from state and municipal governments rose from $22.3 \%$ and $25.5 \%$ respectively in 2003 to $27.0 \%$ and $32.2 \%$ respectively in 2016 . From 2003 to 2014 , total municipal health expenditure per capita (including own resources and revenues from federal and state sources) grew $226 \%$, from $\mathrm{R} \$ 315.7$ to $\mathrm{R} \$ 716.5$ (inflation adjusted). However, since 2015 per-capita expenditure decreased $6.3 \%$ to $\mathbf{R} \$ 617.1$ in 2016 (figure 3).

By contrast, between 2003 and 2016, the federal government's share of health financing fell from $50.0 \%$ to $40.8 \%$ of total public health expenditure. The federal budget is predominantly allocated to servicing debt, which limits the fiscal space available to spend in other areas (figure 4). Debt servicing, which was $50.3 \%$ of federal budget in 2013, rose to $57.0 \%$ in 2016, and represents a considerable financial burden for Brazil. Furthermore, allocations for social security (ie, pensions) have increased from $15.2 \%$ of the federal budget in 2000 to $22.9 \%$ in 2016 , further compromising the availability of funds for health.

\section{RESOURCE ALLOCATION}

Persistent regional and social inequalities in resource allocation left the poor, those with lower education and the populations living in northern regions with greater unmet healthcare needs. ${ }^{26}$ Shortages of doctors persist in rural areas and at PHC level, with specialists concentrated in the private sector and unequally distributed around the country, leading to large disparities. ${ }^{27}$ Although several policies were developed to deal with inequitable distribution of health professionals, unsolved bureaucratic problems in hiring human resources at local levels have led to difficulties in retention of doctors. In response, in 2013, the Rousseff government launched 'More Doctors (Mais Médicos) Programme', to expand PHC by distributing more than 18000 doctors, mostly from Cuba, to underserved areas across the country. ${ }^{27}$

Improving access to medicines was also a priority of Lula and Rousseff governments. National polices have increased the number of drugs available on the essential medicines list from 327 in 2002 to 869 in 2017, improved access to medicines and encouraged the use of generics. ${ }^{28}$ The Popular Pharmacy Program (Farmacia Popular), initiated in 2004, expanded access to medicines with subsidised prices and low level of copayments.

In 2011, a National Commission (Comissão Nacional de Incorporação de Tecnologias) was established to support evidence-based decision-making for adoption of new medicines and technologies in the SUS. ${ }^{29}$ The sizeable demand for medicines in the SUS has encouraged 


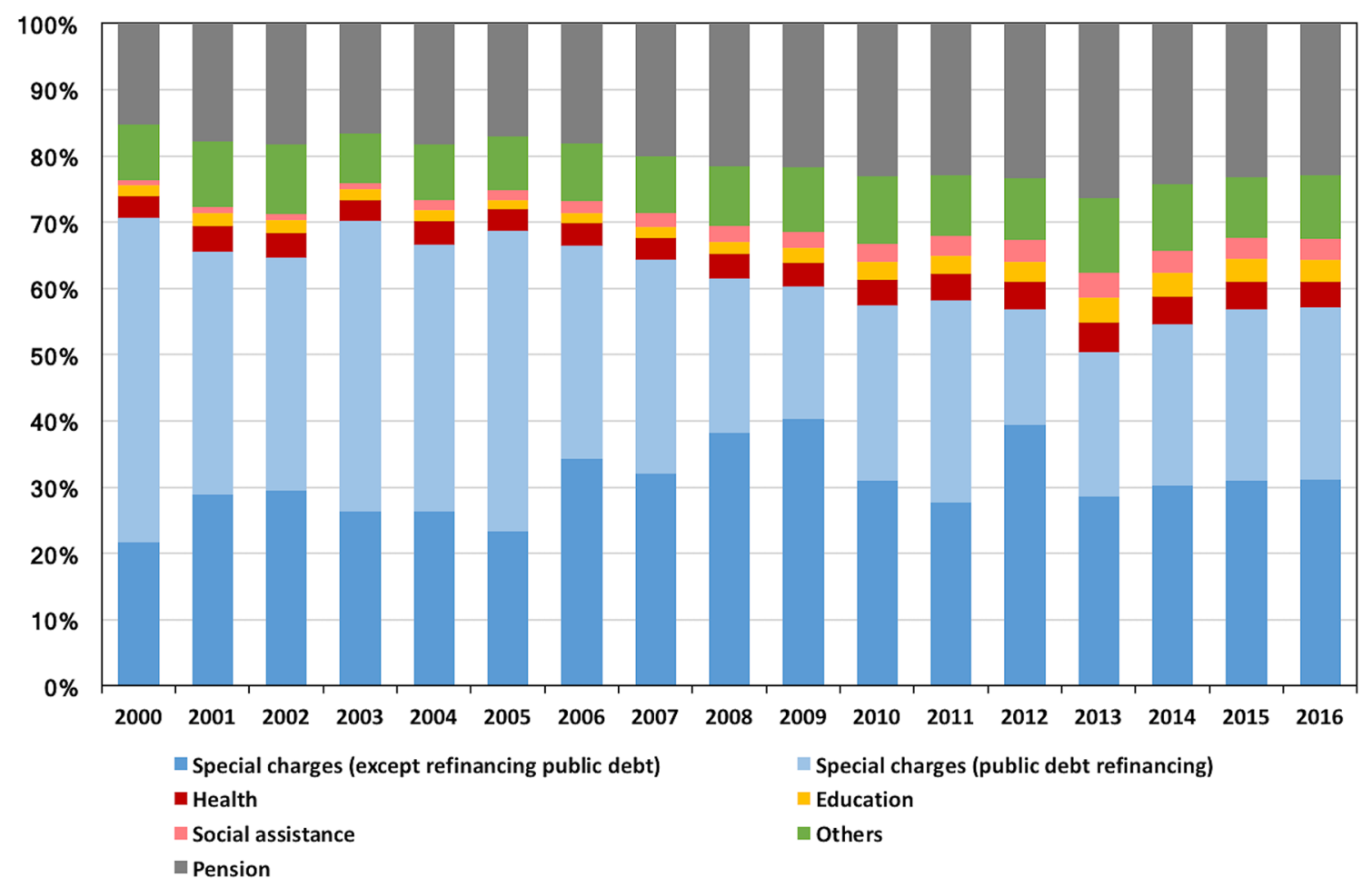

Source: SIAFI - STN/CCONT/GEINC

Figure 4 Percentage of federal government expenditures by function (2000-2016).

industrial domestic production of medicines through public-private partnerships. ${ }^{30}$

Although catastrophic health expenditures have declined since 2004, medicines remain an important component of household budget for the poorest families. ${ }^{31}$

The sustainability of health technology provision in SUS is increasingly challenged by new high-cost medicines and new procedures, which are introduced into SUS as a consequence of 'judicialization' (legal cases brought by individuals claiming their constitutional rights using the judicial system),${ }^{32}$ and ineffective regulation of the medical devices market.

\section{HEALTHCARE COVERAGE}

Expansion of SUS has enabled increased provision of public health programmes (eg, immunisation, tuberculosis and HIV) and complex services (eg, organ transplants, cancer care and kidney dialysis). FHS enabled expansion of PHC as a cost-effective way of covering underserved populations. ${ }^{33}$ In 2000-2016, FHS coverage increased from 13.2 to 120.2 million people (from $7.8 \%$ to $58.5 \%$ of population) (figure 5 ). However, large variability in the quality and productivity of FHS across the country has contributed to disparities in access to PHC. ${ }^{734}$

The National Program for Improving Access and Quality of Primary Care (Programa Nacional de Melhoria do Acesso e da Qualidade da Atenção Básica) was introduced in 2011 and includes a flexible funding component for FHS teams based on performance. ${ }^{35}$
The National Program aims to improve quality, promote health professional development, improve user satisfaction and reorient services to meet local needs. While the effects of this new pay-for-performance scheme are yet to be evaluated, the financial component is relatively small, and the structural problems relating to weakness in local government management capacity, and to recruitment and retention of health professionals are still unresolved. ${ }^{35}$

Since 2004, access to healthcare was further expanded with investment in emergency services (Serviço de Atendimento Móvel de Urgência), emergency clinics (Unidade de Pronto Atendimento) ${ }^{36}$ and mental health centres (Centros de Apoio Psicossocial),${ }^{37}$ aimed at shifting care away from hospitals that are burdened by high demand. Efforts to coordinate regional care with health networks and to improve referral and usage of hospitals have had limited success. ${ }^{10}$ Shortages of certain specialty services and limited administrative capacity have led to poor quality services in hospitals with long waiting times. The interaction among the FHS, hospital system and new emergency services is weak, with duplication and lack of coordination hampering improvements in providing effective and efficient care. ${ }^{10}$

Parallel to expanded coverage by the publicly financed SUS, medical private insurance coverage has increased since 2000 from 30.5 million in 2000 to 50.3 million in $2014(17.6 \%-24.8 \%$ of population respectively). In 2017, private insurance coverage declined to 47.3 million (22.8\% of population), as income and employment levels 


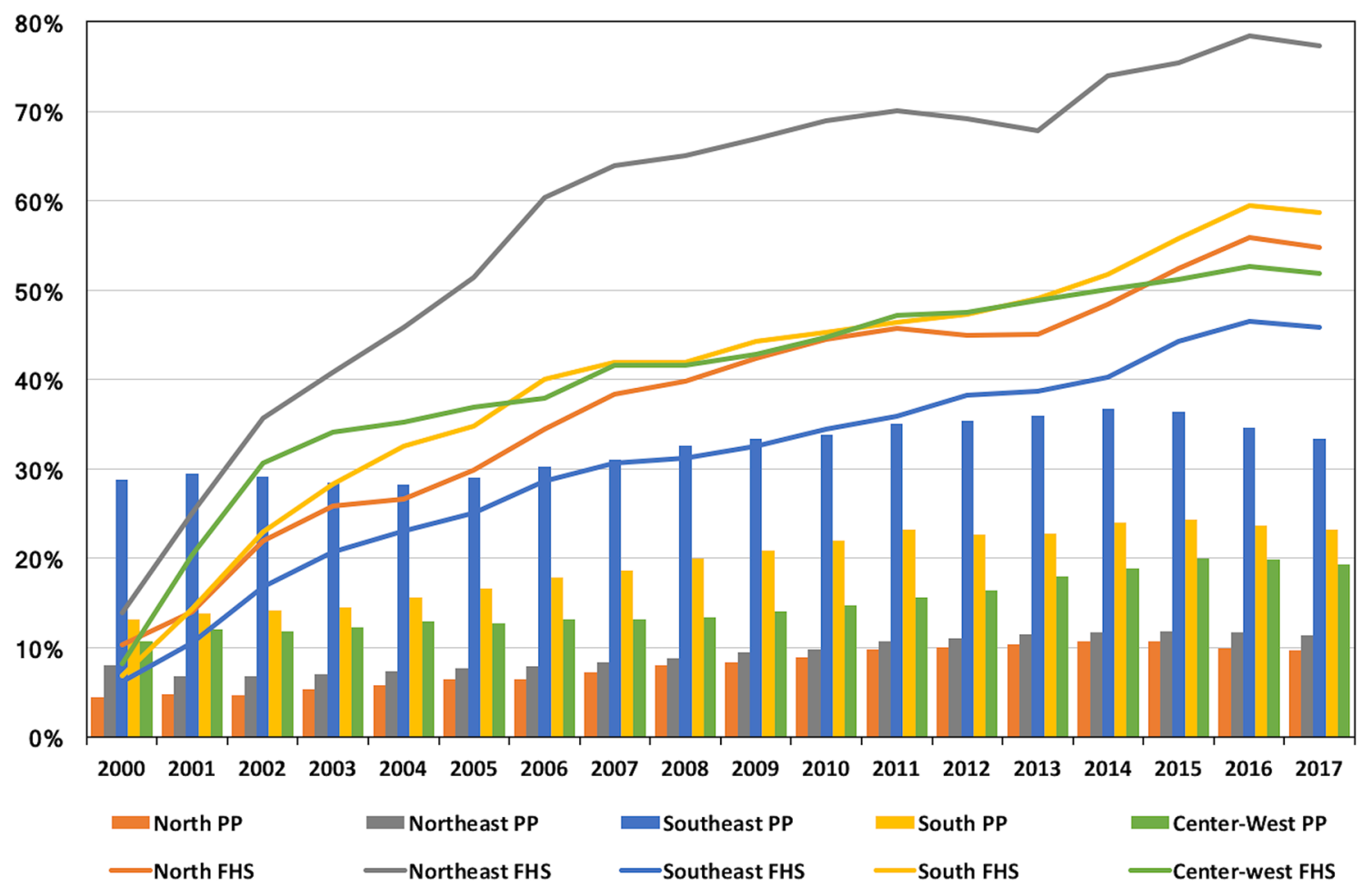

Sources: DAB/Ministry of Health, ANS - Agencia Nacional de Saúde Suplementar

Figure 5 Population covered by the Family Health Strategy (FHS) and by Medical Private Plans (PP), Brazil 2000-2017.

fell. Although the 1988 Constitution defined that the private sector should be complementary to public sector, in practice it is partly subsidised by the government through tax breaks for privately insured individuals, who obtain high-complexity procedures in SUS, due to limited coverage of these procedures in private insurance plans, or low levels of reimbursement of patient costs. ${ }^{25}$

The growth of the FHS and private plans has increased coverage of health services, but large disparities remain among regions, and many disadvantaged populations still lack access to high-quality care (figure 5).

\section{WORSENING ECONOMIC AND POLITICAL CRISES}

The political and economic crises in Brazil are having their toll. Between 2014 and 2016, the gross national income per capita fell sharply from US $\$ 12202$ to US $\$ 8840$, while those living in poverty (at less than US $\$ 5.5$ a day) increased from $20.4 \%$ to $23.5 \%$ of the population, ${ }^{38}$ and more than 100000 people became homeless. ${ }^{39}$ Over this period, 2.9 million people lost private medical insurance. In the third quarter of 2017, unemployment and underemployment rates were $12.4 \%$ and $23.9 \%$, respectively. ${ }^{40}$

Homicides, which rose between 2005 and 2014, but declined in 2015, rose again in 2016, reaching 61 283the highest on record in Brazil. ${ }^{41}$ In 2016 there were 45568 attempts of self-harm, $34.6 \%$ higher than in $2014 .{ }^{42}$ Further studies are needed to establish whether these increases are just associations or as a result of the crises and austerity measures experienced in Brazil.
Infectious diseases, which were previously under control or were steadily declining, are rising, including outbreaks of yellow fever recorded in 2016 and 2018 (which may have been due to a fall in vaccination in risk regions or the environmental disaster that followed the collapse of the Samarco dam in Minas Gerais, which may have displaced non-human primates whose habitats were destroyed) ${ }^{43}$ resurgence of syphilis in pregnancy between 2010 and $2015,{ }^{44}$ malaria ${ }^{45}$ and dengue (with the highest recorded cases in 2015-2016). ${ }^{46}$ While new infectious diseases such as Chikungunya and Zika viruses ${ }^{46}$ have emerged. The latest mortality statistics are expected to show that children, the elderly and vulnerable groups are affected by the crisis in terms of preventable causes of mortality. ${ }^{47}$ Again, while there is an observed association, further studies are needed for each condition briefly discussed here to establish whether these increases are directly as a consequence of the crises and austerity measures experienced in Brazil or other factors.

\section{HEALTH SYSTEM RESILIENCE}

Investments in the health system would enhance the resilience of SUS and enable it to better absorb the adverse effects of the economic and political shocks. Yet, since 2015, there has been a reduction in the average per-capita funds allocated by municipalities to SUS, exacerbating historical underfunding and resource scarcity in the health system, and according to recent media reports leading to shortages of basic medicines, worsening 
working conditions for health professionals and shortages of doctors in public health facilities, especially hospitals where patients face long queues. ${ }^{48}$

Despite budgetary constraints, SUS is still providing care for the majority of Brazilians, including those who have lost private health insurance plans recently. ${ }^{49}$ Although the hospital services are under pressure, FHS coverage has remained relatively stable during the economic and political crises, supported at local levels through the More Doctors Programme. However, recent policy decisions have altered the allocations to FHS funding and modified the federally defined FHS model. These new short-sighted policies, which make it possible to divert funds from FHS and change the multiprofessional nature of FHS teams, will undermine key principles and the success of PHC, specifically its comprehensive nature and the family and community focus. In some cities, the consequences of a weakening PHC service are evident, with citizens forgoing healthcare and in increased use of emergency services. The precariousness of SUS and limited access to expensive private plans is creating a new market for low-cost outpatient care carried out by 'popular' private clinics, paid out of pocket by patients. ${ }^{49}$

\section{LOOKING AHEAD}

Although the long-term impact of the crisis and austerity measures is yet to fully unfold, the adverse effects on health outcomes and inequalities are likely to more intense in the highly unequal Brazil than what might be experienced in high-income countries. Despite achievements in the last decade in overcoming extreme poverty and hunger, structural social problems that have plagued the country will make these achievements easily reversible. Likewise, health system progress achieved in the last two decades is unlikely to be sustained due to underfinancing, austerity measures and inefficient allocation of resources that will be exacerbated by new policies.

The current government's message that austerity is a necessity within public services has been welcomed by some politicians in Brazil ${ }^{24}$ against international evidence that this is neither wise nor necessary. ${ }^{250}$ If austerity policies are fully implemented, Brazil could face a public health crisis, ${ }^{47}$ with reversal of the achievements in relation to social determinants of health and with emergence of further segregation, ${ }^{50}$ leading to a tripartite system with financially depleted SUS serving the poor, 'limited-coverage' private plans for the middle class, and high-quality and high-cost interventions available to the wealthy. This is a recipe for further segregation that will only serve to widen already sizeable health inequalities, undermine UHC and worsen poverty.

The political and economic crises have shaken SUS, and constitutional rights to health have been undermined through austerity policies of the current government. The prospect of long-term freeze on public expenditures creates a situation which makes it increasingly impossible for the universality and comprehensiveness principles of the SUS to be pursued and sustained.

Given Brazil's sizeable inequalities and unresolved health burdens, reversing progress to UHC could have a major detrimental impact on the poorest and the most vulnerable populations, and fracture the hard-earned social contract of the postmilitary dictatorship era. There is hence an imperative to very carefully monitor changes in key health indicators, population health outcomes and impoverishing expenditures to ensure any adverse effects are noted early and appropriate polices introduced to ensure protection of those adversely affected.

As Brazil struggles to preserve its achievements during the political and economic turbulence, the unfolding folly in its health system provides important lessons for other countries, which, we hope, should be wise enough to not replicate the mistakes currently made in Brazil.

Acknowledgements The authors are grateful for the support and cooperation of the Federal University of Parana and the Brazilian Office of the Pan-American Health Organization/World Health Organization in Brazil.

Contributors RA and AM conceived the study. AM developed the first draft with guidance from RA and input from coauthors. All authors contributed to the final draft.

Funding AM was funded by the Pan-American Health Organization/World Health Organization in Brazil.

Competing interests None declared.

Patient consent Not required.

Provenance and peer review Not commissioned; externally peer reviewed.

Data sharing statement No additional unpublished data from the study are available.

Open access This is an open access article distributed in accordance with the Creative Commons Attribution Non Commercial (CC BY-NC 4.0) license, which permits others to distribute, remix, adapt, build upon this work non-commercially, and license their derivative works on different terms, provided the original work is properly cited, appropriate credit is given, any changes made indicated, and the use is non-commercial. See:Chttp://creativecommons.org/licenses/by-nc/4.0/.

\section{REFERENCES}

1. Pan American Health Organization. Resolution CD53.R14: strategy for universal access to health and universal health coverage. 53rd directing council, 66th session of the regional committee of WHO for the Americas. Washington, D.C., USA: Pan American Health Organization (PAHO), 2014.

2. Karanikolos M, Mladovsky P, Cylus J, et al. Financial crisis, austerity, and health in Europe. The Lancet 2013;381:1323-31.

3. Horton R. Offline: the possible impossibility of universal health coverage. Lancet 2017;389:140.

4. Atun R, de Andrade LOM, Almeida G, et al. Health-system reform and universal health coverage in Latin America. The Lancet 2015;385:1230-47.

5. Paim J, Travassos C, Almeida C, et al. The Brazilian health system: history, advances, and challenges. The Lancet 2011;377:1778-97.

6. Barreto ML, Rasella D, Machado DB, et al. Monitoring and evaluating progress towards Universal Health Coverage in Brazil. PLoS Med 2014;11:e1001692.

7. Hone T, Rasella D, Barreto M, et al. Large reductions in amenable mortality associated with brazil's primary care expansion and strong health governance. Health Aff 2017;36:149-58.

8. Macinko J, Dourado I, Aquino R, et al. Major expansion of primary care in Brazil linked to decline in unnecessary hospitalization. Health Aff 2010;29:2149-60.

9. Santos NR. [The Brazilian Unified Health System (SUS), State Public Policy: its institutionalized and future development and the search for solutions]. Cien Saude Colet 2013;18:273-80. 
10. Gragnolati M, Lindelow M, Couttolenc B. Twenty years of health system reform in Brazil: an assessment of the Sistema Unico de Saude. World Bank Publications 2013.

11. Rossi P, Dweck E. Impacts of the new fiscal regime on health and education. Cad Saude Publica 2016;32:e00194316.

12. Thomas S, Keegan C, Barry S, et al. A framework for assessing health system resilience in an economic crisis: Ireland as a test case. BMC Health Serv Res 2013;13:450.

13. Vieira FS, E Benevides RPDS. O Direito à Saúde no Brasil em Tempos de Crise Econômica, Ajuste Fiscal e Reforma Implícita do Estado. Revista de Estudos e Pesquisas sobre as Américas 2016;10:28.

14. Maruthappu M, Watkins J, Noor AM, et al. Economic downturns, universal health coverage, and cancer mortality in high-income and middle-income countries, 1990-2010: a longitudinal analysis. Lancet 2016;388:684-95

15. Maruthappu M, Watson RA, Watkins J, et al. Effects of economic downturns on child mortality: a global economic analysis, 19812010. BMJ Glob Health 2017;2:e000157.

16. Williams C, Gilbert BJ, Zeltner T, et al. Effects of economic crises on population health outcomes in Latin America, 1981-2010: an ecological study. BMJ Open 2016;6:e007546.

17. Ng KY, Maruthappu M, Farrukh J, et al. The effect of economic downturns on maternal mortality among pregnancies with abortive outcomes in 81 countries, 1981-2010. Int J Gynaecol Obstet 2015;130:169-73

18. Maruthappu M, Ng KY, Williams C, et al. Government health care spending and child mortality. Pediatrics 2015;135:e887-e894.

19. International Monetary Fund (IMF). Brazil: 2017 Article IV Consultation-Press Release; Staff Report; and Statement by the Executive Director for Brazil. Washington, D.C. USA: International Monetary Fund (IMF), 2017

20. Skoufias E, Nakamura S, Gukovas RM. Safeguarding against a reversal in social gains during the economic crisis in Brazil. Working Paper 112896. Washington, DC, USA: The World Bank, 2017.

21. European Central Bank. What is driving Brazil's economic downturn? Economic Bulletin Issue 1 / 2016. Frankfurt, Germany: European Central Bank, 2016

22. BBC News. Brazil launches rescue plan to fix economy: BBC. 2016 http://www.bbc.com/news/business-37357657 (accessed 21 Sep 2016).

23. Ministry of Health of Brazil. Ordinance 381/2017. Brasilia, Brazil: Ministry of Health of Brazil, 2017.

24. Doniec K, Dall'Alba R, King L. Austerity threatens universal health coverage in Brazil. The Lancet 2016;388:867-8.

25. Bahia L, Scheffer M, Poz MD, et al. Private health plans with limited coverage: the updated privatizing agenda in the context of Brazil's political and economic crisis. Cad Saude Publica 2016;32:e00184516.

26. Albuquerque MV, Viana ALD, Lima LD, et al. Regional health inequalities: changes observed in Brazil from 2000-2016. Cien Saude Colet 2017;22:1055-64.

27. Oliveira APC, Gabriel M, Poz MRD, et al. Challenges for ensuring availability and accessibility toin health care services under Brazil's Unified Health System (SUS). Cien Saude Colet 2017;22:1165-80.

28. Tavares NUL, Luiza VL, Oliveira MA, et al. Free access to medicines for the treatment of chronic diseases in Brazil. Revista de Saúde Pública 2016;50(suppl 2):7.

29. Elias FT, Araújo DV. How health economic evaluation (HEE) contributes to decision-making in public health care: the case of Brazil. Z Evid Fortbild Qual Gesundhwes 2014;108:405-12.

30. Viana AL, Silva HP, Ibañez N, et al. Development policy for the Brazilian health industry and qualification of national public laboratories. Cad Saude Publica 2016;32(Suppl 2):e 00188814.

31. Boing $A C$, Bertoldi AD, Boing AF, et al. [Access to medicines in the public sector: analysis of users of the Brazilian Unified National Health System]. Cad Saude Publica 2013;29:691-701.
32. Chieffi AL, Barradas RCB, Golbaum M. Legal access to medications: a threat to Brazil's public health system? BMC Health Serv Res 2017; 17:499.

33. Macinko J, Harris MJ. Brazil's family health strategy--delivering community-based primary care in a universal health system. $N$ Engl J Med 2015;372:2177-81.

34. Hone T, Rasella D, Barreto ML et al. Association between expansion of primary healthcare and racial inequalities in mortality amenable to primary care in Brazil: A national longitudinal analysis. PLoS Med 2017; 14:e1002306.

35. Macinko J, Harris MJ, Rocha MG. Brazil's National Program for Improving Primary Care Access and Quality (PMAQ): fulfilling the potential of the world's largest payment for performance system in primary care. J Ambul Care Manage 2017;40(Suppl 2):S4.

36. O'Dwyer G, Konder MT, Machado CV, et al. The current scenario of emergency care policies in Brazil. BMC Health Serv Res 2013;13:70.

37. Machado DB, Alves FJ, Rasella D, et al. Impact of the new mental health services on rates of suicide and hospitalisations by attempted suicide, psychiatric problems, and alcohol problems in Brazil. Administration and Policy in Mental Health and Mental Health Services Research 2017:9:1.

38. World Bank. Country Poverty Brief. Brazil, October 2017. www. worldbank.org/poverty (accessed 20 Nov 2017).

39. Natalino MAC. Estimativa da População em Situação de Rua no Brasil. Discussion Paper 2246. Brasília, DF, Brazil: Instituto de Pesquisa Econômica Aplicada - IPEA, 2016.

40. Brazilian Institute of Geography and Statistics (IBGE). National Continuous Household Sample Survey - PNAD Continuous. http:// www.ibge.gov.br (accessed 8 Nov 2017).

41. Brazilian Forum of Public Security. Statistical yearbook of public security. $2017 \mathrm{http}: / / \mathrm{www}$.forumseguranca.org.br/ativities/anuario (accessed 27 Nov 2017)

42. Secretariat of Health Surveillance, Ministry of Health of Brazil. Epidemiological profile of suicide attempts and deaths in Brazil and a health care network. Epidemiological Bulletin. http://portalsaude. saude.gov.br/index.php/o-ministerio/principal/secretarias/svs/bole timepidemiologico (accessed 1 Dec 2017)

43. Secretariat of Health Surveillance, Ministry of Health of Brazil. Epidemiological emergency of yellow fever in Brazil, from December 2016 to July 2017. Epidemiological Bulletin. http://portalsaude. saude.gov.br/index.php/o-ministerio/principal/secretarias/svs/bole timepidemiologico (accessed 20 Nov 2017).

44. Secretariat of Health Surveillance, Ministry of Health of Brazil Epidemiological Bulletin of Syphilis 2017. http://www.aids.gov.br/ptbr/tags/publicacoes/boletim-de-sifilis (accessed 20 Nov 2017).

45. Secretariat of Health Surveillance, Ministry of Health of Brazil. Historical series of Malaria notification cases. http://portalms.saude. gov.br/saude-de-a-z/malaria (accessed 20 Nov 2017).

46. Secretariat of Health Surveillance, Ministry of Health of Brazil. Monitoring of cases of dengue fever, chikungunya fever and fever by the virus Zika ate an Epidemiological Week 35 of 2017. http://portalsaude.saude.gov.br/index.php/o-ministerio/principal/ secretarias/svs/boletim-epidemiological (accessed 20 Nov 2017).

47. Observatory of Political Analysis in Health. Bulletin of the Project of analysis of health policies in brazil, year $02,8,2016$. Crisis in brazil: what are the impacts on the health of the population? http://www. analisepoliticaemsaude.org/oaps/boletim/edicao/8 (accessed 1 Aug 2017).

48. Watts J. Brazil's health system woes worsen in economic crisis. Lancet 2016;387:1603-4.

49. Lenharo $M$. Quem sao os brasileiros que deixaram o plano de saude e como estao se cuidando? G1. Mar 15, 2017. https://g1.globo. $\mathrm{com} /$ bemestar/noticia/quem-sao-os-brasileiros-que-deixaram-oplano-de-saude-e-como-estao-se-cuidando.ghtml (accessed 20 Aug 2017).

50. Quaglio G, Karapiperis T, Van Woensel L, et al. Austerity and health in Europe. Health Policy 2013;113:13-19. 